\title{
Equipment
}

\author{
J. Jeff Andrews MD, Robert V. Johnston Jr. MD \\ George C. Kramer PhD
}

\section{Consequences of misfilling contemporary vaporizers with desflurane}

Desflurane is a volatile anaesthetic that combines low blood gas solubility (blood/gas partition coefficient $=0.42$ at $37^{\circ}$ C), moderate potency (MAC $=6-7 \%$ ), and high volatility (vapour pressure $=681 \mathrm{mmHg}$ at $20^{\circ} \mathrm{C}$, boiling point $=23.5^{\circ}$ C). The volatility and potency of desflurane prevent its safe use in vaporizers of traditional design. We present a mathematical model which demonstrates the potential for desflurane overdose if contemporary vaporizers are misfilled with desflurane. The most hazardous filling error occurs if an enflurane vaporizer is misfilled with desflurane. The calculated desflurane output of a misfilled enflurane vaporizer at a dial setting of $1 \%$ and a temperature of $22^{\circ} \mathrm{C}$ is $57.8 \%$, or $9.6 \mathrm{MAC}$. For misflled enflurane, isoflurane, and halothane vaporizers at dial settings equivalent to one $M A C$ at $22^{\circ} \mathrm{C}$, the calculated desflurane output is $14.0,10.2$, and $7.8 \mathrm{MAC}$, respectively. We conclude that the safe delivery of desflurane will require engineering safeguards, additional monitoring, and education of the anesthesia community.

\section{Key words}

ANAESTHETICS, GASES: desflurane; EQUIPMENT: vaporizers.

From the Department of Anesthesiology, The University of Texas Medical Branch, Galveston, Texas.

Address correspondence to: Dr. J. Jeffrey Andrews,

Department of Anesthesiology, E-91, The University of Texas Medical Branch, Galveston, Texas 77555-0591, Tel: (409) 772-1221, Fax: (409) 772-1224 or (409) 772-4385.

This departmentally funded investigation was performed in the research laboratory of the Department of Anesthesiology at the University of Texas Medical Branch in Galveston, Texas. It was presented in abstract form at the Annual Meeting of the American Society of Anesthesiologists, 28 October 1991, San Francisco, CA.

Accepted for publication 3rd September, 1992.
Le desflurane est un anesthésique volatil caractérisé par un degré de solubilité sanguine peu élevé (coefficient-partage sang) gaz $=0,42$ à $\left.37^{\circ} \mathrm{C}\right)$, une puissance intermédiaire $(\mathrm{MAC}=$ $6-7 \%$ ) et une volatilité élevée (pression de vapeur $=681 \mathrm{~mm} \mathrm{Hg}$ à $20^{\circ} \mathrm{C}$, point d'ébullition $=23,5^{\circ} \mathrm{C}$ ). La volatilité et la puissance du desflurane préviennent son usage en toute sécurité dans les vaporisateurs utilisés actuellement. Nous présentons un modèle qui illustre pour le desflurane le danger de surdosage si on fait l'erreur de remplir les vaporisateurs actuels avec cet agent. Le débit calculé d'un vaporisateur à enflurane chargé au desflurane avec manette de calibrage règlé à $1 \%$, à une température de $22^{\circ} \mathrm{C}$, est de $57,8 \%$ ou 9,6 MAC. Pour les vaporisateurs d'enflurane, isoflurane et halothane à des ajustements de contrôle à $1 \mathrm{MAC}$, les débits calculés de desflurane le situent respectivement à $14,0,10,2$ et 7,8 MAC. Nous concluons que l'administration en toute sécurité du desflurane nécessitera des balises techniques, un monitorage supplémentaire et des études de la part des d'utilisateurs.

Desflurane is a new inhaled anaesthetic with unique physical properties. Its chemical structure is identical to isoflurane except that fluorine is substituted for chlorine on the alpha ethyl carbon. The vapour pressure of desflurane $\left(681 \mathrm{mmHg}\right.$ at $20^{\circ} \mathrm{C}$ ) is three to four times that of contemporary agents, and it boils near room temperature $\left(23.5^{\circ} \mathrm{C}\right) .^{1}$ Desflurane is moderately potent with MAC values of $6-7 \% .^{2}$ High volatility combined with moderate potency precludes its use with standard vaporizers.

Desflurane has a low blood gas solubility coefficient of 0.42 at $37^{\circ} \mathrm{C}$, which is similar to that of nitrous oxide. ${ }^{3}$ Therefore, recovery from anaesthesia with desflurane is more rapid than with other potent inhaled anaesthetics. ${ }^{4}$ Biotransformation is minimal, and hepato-renal function is unaffected after exposure to desflurane. ${ }^{5}$ These properties make desflurane a potentially valuable anaesthetic.

The availability of multiple halogenated agents promotes the potential for misfilling vaporizers. When methoxyflurane was introduced in 1960 , the potential for a 
lethal filling error was created. If the agent-specific Pentec ${ }^{\circledR}$ methoxyflurane vaporizer was accidentally filled with halothane, as much as $15-20 \%$ halothane could be delivered. ${ }^{6}$ This overdose would occur because the methoxyflurane vaporizer was designed for use with a liquid with a lower vapour pressure $\left(22.8 \mathrm{mmHg}\right.$ at $\left.20^{\circ} \mathrm{C}\right)$ than that of halothane $\left(243 \mathrm{mmHg}\right.$ at $\left.20^{\circ} \mathrm{C}\right)$. Many safety features, such as keyed fillers and colour coding, have been implemented since that time. ${ }^{7}$ Nevertheless, vaporizer misfillings are common with funnel-type fillers, and they can occur with keyed fillers. ${ }^{8-10}$

The consequences of filling vaporizers specifically designed for enflurane, isoflurane, and halothane with desflurane should be quantitatively similar to filling a methoxyflurane-specific vaporizer with halothane because desflurane's vapour pressure considerably exceeds that of the other three inhaled anesthetics. To quantify the consequences, we developed a mathematical model to predict the effects of misfilling contemporary vaporizers with desflurane.

\section{Methods}

We derived the Clausius-Clapeyron equation for desflurane using a linear least-squares fit of the logarithm of vapour pressure (log VP) versus reciprocal absolute temperature $(1 / T K)$ using four temperature-specific values for desflurane vapour pressures provided by Anaquest, desflurane's manufacturer. (The vapour pressures for desflurane at $20,22,24$, and $26^{\circ} \mathrm{C}$ are $681,743,811$, and $885 \mathrm{mmHg}$, respectively.) The desflurane vapour pressure curve was calculated from the derived ClausiusClapeyron equation. The vapour pressure curves for enflurane, isoflurane, and halothane were generated from published Antoine equations. "

We modeled the consequences of misfilling contemporary vaporizers with desflurane using the following equation derived from Dorsch. ${ }^{12}$ The derivation is shown in Appendix A.

\% Des $=\frac{\left(\frac{\text { Dial Set }}{100-\text { Dial Set }}\right)\left(\frac{\mathrm{VP}_{\text {des }}}{\mathbf{P}_{\text {atm }}-\mathrm{VP}_{\text {des }}}\right)\left(\frac{\mathbf{P}_{\text {atm }}-\mathrm{VPa}}{\mathrm{VP}_{\mathrm{a}}}\right) \times 100}{1+\left(\frac{\text { Dial Set }}{100-\text { Dial Set }}\right)\left(\frac{\mathrm{VP}_{\text {des }}}{\mathbf{P}_{\text {atm }}-\mathrm{VP}_{\text {ded }}}\right)\left(\frac{\mathbf{P}_{\text {atm }}-\mathrm{VPa}}{\mathrm{VPa}}\right)}$

where

$\%$ Des $=$ Output of desflurane in percent

Dial Set $=$ Dial setting of the vaporizer in percent

$V P_{\text {des }}=$ Vapour pressure of desflurane

$P_{\text {atm }}=$ Atmospheric pressure

$\mathrm{VPa}=$ Vapour pressure of the agent intended for use in the agent-specific vaporizer

\section{Anaesthetic Vapor Pressure vs Temperature}

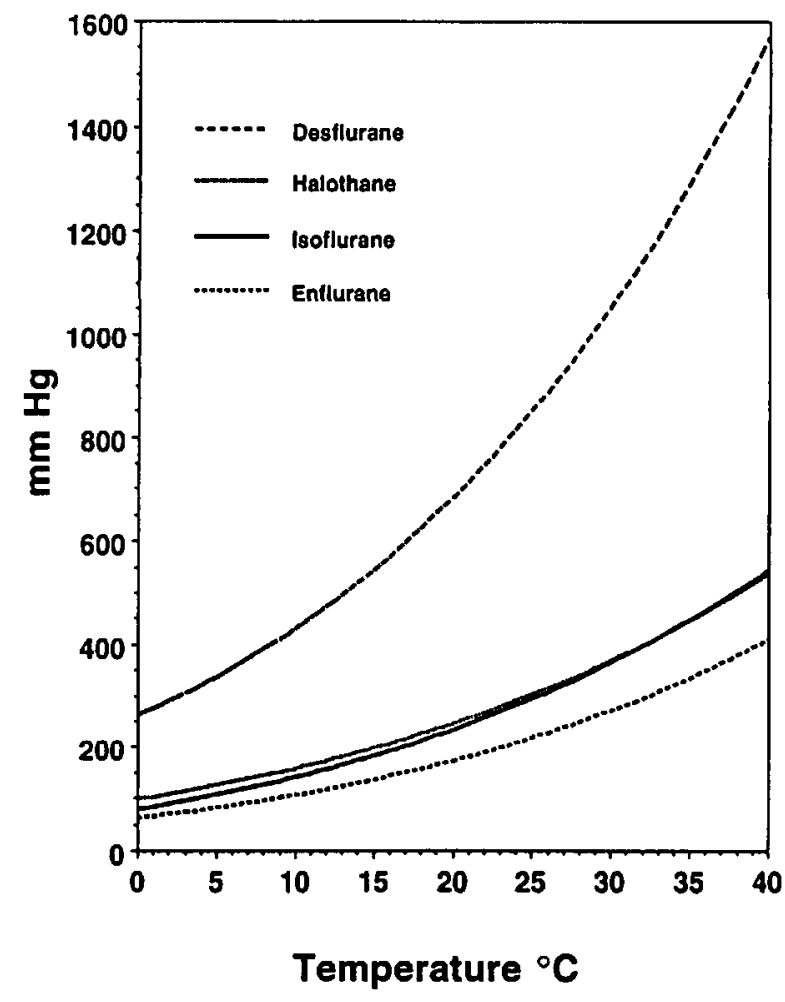

FIGURE 1 Anaesthetic vapour pressures versus temperature curves for enflurane, isoflurane, halothane, and desflurane.

\section{Results}

Vapour pressure versus temperature curves

Figure 1 shows the vapour pressures as a function of temperature for desflurane, halothane, isoflurane, and enflurane. The derived Clausius-Clapeyron equation for desflurane is $\log$ VP $=8.515-1665.9 / \mathrm{TK}$; where VP is vapour pressure $(\mathrm{mmHg})$ and $\mathrm{TK}$ is degrees Kelvin. The calculated heat of vaporization is $40 \mathrm{cal} / \mathrm{gram}$. The vapour pressure curve for desflurane is both steeper and shifted to higher vapour pressures when compared to the curves for the standard potent volatile agents. Desflurane's boiling point is approximately $23.5^{\circ} \mathrm{C}$.

Misfilling contemporary vaporizers with desflurane

Figure 2 illustrates the calculated desflurane output (in percent) of misfilled contemporary vaporizers at dial settings ranging from 0 to $5 \%$ and at temperatures of 19 , 20,21 , and $22^{\circ} \mathrm{C}$. As expected, the most hazardous misfilling would occur if an enflurane vaporizer, specific for the agent which has the lowest vapour pressure of commonly used halogenated agents, is filled with desflurane. The calculated desflurane output at a dial setting 


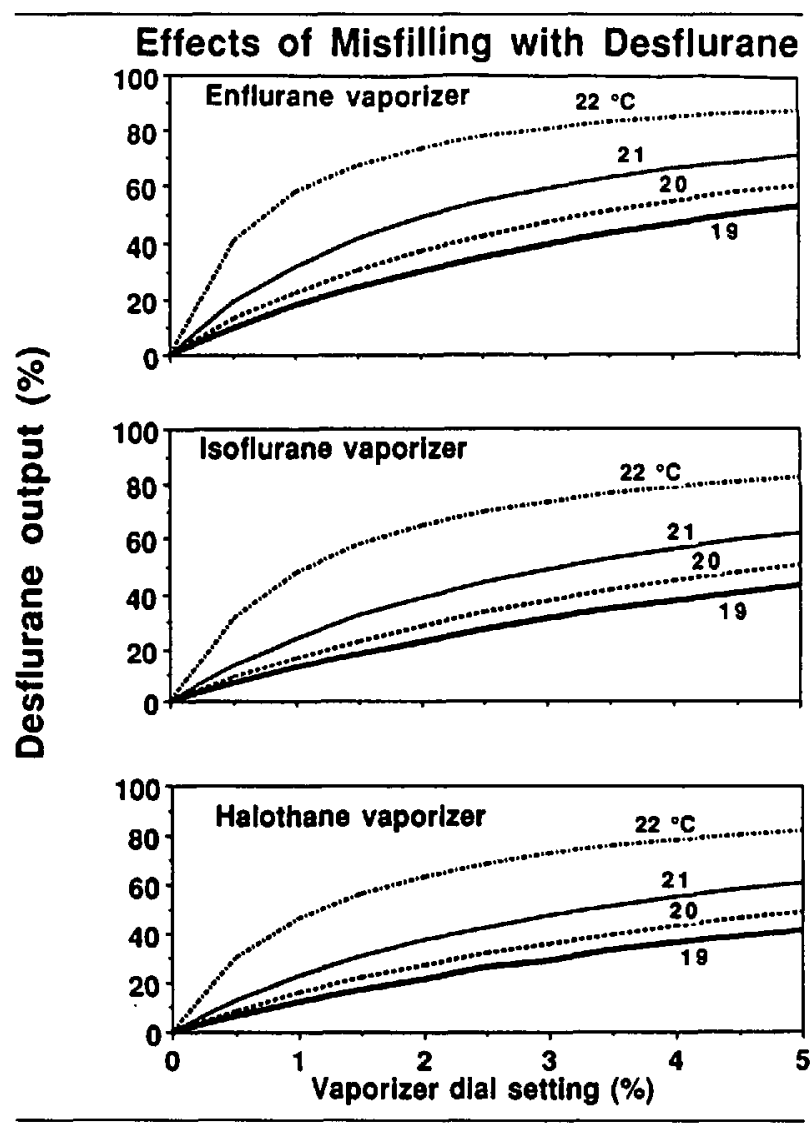

FIGURE 2 Desflurane output of contemporary vaporizers misfilled with desflurane at $19,20,21$, and $22^{\circ} \mathrm{C}$.

of $1 \%$ and a temperature of $22^{\circ} \mathrm{C}$ is $57.8 \%$, or $9.6 \mathrm{MAC}$ desflurane. If the composition of the fresh gas-flow is $30 \%$ oxygen and $70 \%$ nitrous oxide, the oxygen concentration would be $30 \%$ of $42.2 \%$, or $12.66 \%$ oxygen. Figure 3 demonstrates the relationship between the apparent MAC set on the vaporizer dial versus the MAC output of desflurane at $22^{\circ} \mathrm{C}$. When the dial setting is equivalent to one MAC of enflurane, isoflurane, or halothane, the calculated output of desflurane is 14.0, 10.2 and $7.8 \mathrm{MAC}$, respectively.

\section{Discussion}

Our mathematical model predicts that misfilling contemporary vaporizers with desflurane can produce both an extreme overdose and an hypoxic gas mixture, even at temperatures below the $23.5^{\circ} \mathrm{C}$ boiling point. Overpressurization of this order of magnitude is not possible with any other contemporary inhaled anaesthetic. Because desflurane is very insoluble in blood and tissues, such an overdose will cause an extremely rapid wash-in of desflurane. The net effect could be rapid and precipitous central nervous system and cardiovascular depression. To diagnose this extremely hazardous situation quickly, con-

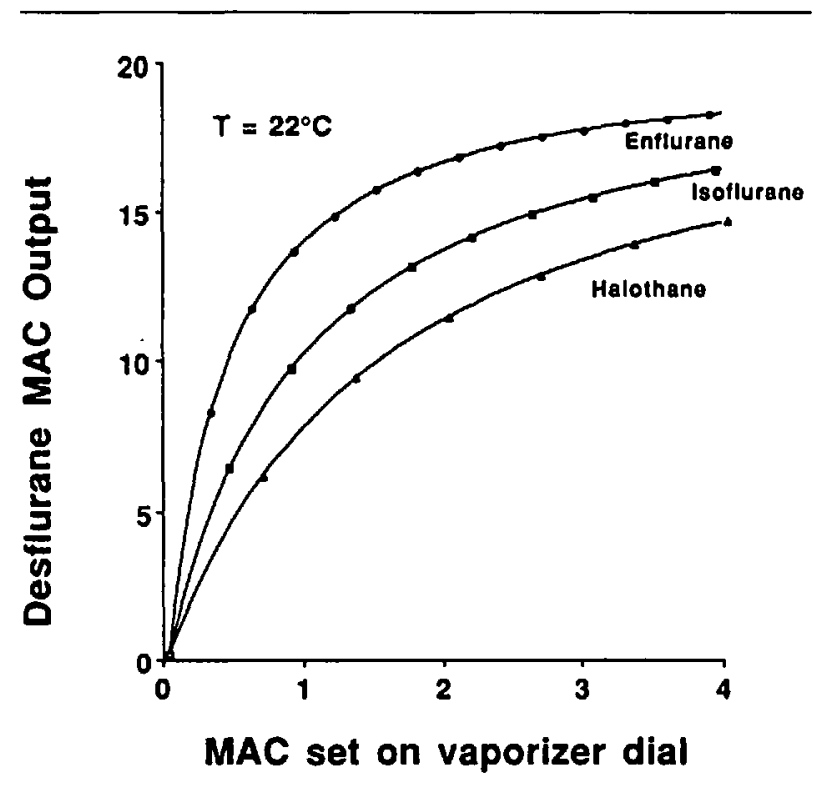

FIGURE 3 Desflurane output with misfilled contemporary vaporizers at $22^{\circ} \mathrm{C}$. The MACs used to generate this graph were 0.75 , $1.15,1.68$, and $6.0 \%$ for halothane, isoflurane, enflurane, and desflurane, respectively.

tinuous gas analysis, with a monitor that has an agent identification feature, is indicated in all cases where desflurane may be used.

In a clinical situation, the actual desflurane output will rapidly decrease to less than the predicted values because the model does not take into account vaporizer cooling, which will occur when large quantities of liquid desflurane are vaporized. For a Tec 5 enflurane vaporizer misfilled with desflurane at $22^{\circ} \mathrm{C}$, at a dial setting of $5 \%$ with a fresh gas flow rate of $5 \mathrm{~L} \cdot \mathrm{min}^{-1}$, we estimate the initial rate of vaporizer cooling to be $15^{\circ} \mathrm{C} \cdot \mathrm{min}^{-1}$ (see appendix B for estimation). This rapid cooling will self-limit the rapid massive vaporization. The rate of vaporizer cooling depends upon (1) which agent-specific vaporizer is misfilled, (2) the quantity of liquid desflurane instilled, (3) the dial setting, (4) the fresh gas flow rate, (5) the ambient temperature, and (6) the design, mass, and composition of the vaporizer. A study using actual contemporary vaporizers misfilled with desflurane would be necessary to determine actual output with time.

The manufacturer has introduced an unique agentspecific filling system in an attempt to prevent misfillings. The cap of the desflurane bottle is an agent-specific, keyed, filler, which fits only into the filler port of the new Tec 6 desflurane vaporizer. The bottle cannot be used with standard vaporizers. ${ }^{13}$ The filling system does not address, however, the potential hazard of misfilling contemporary vaporizers with desflurane obtained by draining a desflurane vaporizer into a non-keyed bottle. 
To prevent this hazard, the manufacturer recommends disposal of the liquid drained from desflurane vaporizers. ${ }^{13}$

Controlled vaporization of desflurane will require new vaporizer technology because of its unique physical properties. The new Tec 6 vaporizer is electrically heated and thermostatically controlled to $39^{\circ} \mathrm{C}$, a temperature well above desflurane's boiling point. At $39^{\circ} \mathrm{C}$, the vapour pressure inside the vaporizer sump assembly is approximately $1500 \mathrm{mmHg}$ absolute, or 2 atmospheres. ${ }^{13}$ The heated sump provides a constant reservoir of desflurane vapour much as a cyclopropane cylinder provides a reservoir of cyclopropane vapour.

\section{Conclusions and recommendations}

Desflurane presents unique challenges in controlled vaporization and patient safety. Specific engineering efforts have been made to minimize the chance of misfilling contemporary vaporizers with desflurane. Nevertheless, if desflurane is used, we recommend an oxygen analyzer, pulse oximetry, and continuous agent gas analysis. Gas analyzers with an agent identification feature would be preferable to those which require the operator to identify the gas. The most important safeguard to help insure the safe delivery of desflurane, however, is thorough education of the anaesthesia community regarding the unique properties of desflurane.

\section{Acknowledgements}

The authors wish to thank Andy Tran, Senior Medical Student, for his help in generation of the Figures, and Ms. Christy Perry for manuscript preparation.

\section{Appendix A}

The output flow of the vaporizing chamber $\left(\mathrm{CF}_{\text {oud }}\right)$ equals the flow of gas entering the vaporizing chamber $\left(\mathrm{CF}_{\text {in }}\right)$ plus the flow of agent which is entrained. The amount of agent entrained is the product of the flow entering the vaporizing chamber $\left(\mathrm{CF}_{\mathrm{in}}\right)$ multiplied by the volume expansion coefficient (VEX). Volume expansion coefficient is defined as vapour pressure of the agent (VPa) divided by operating pressure (Ps) minus VPa. The volume expansion coefficients at $760 \mathrm{mmHg}$ and $20^{\circ} \mathrm{C}$ for enflurane, isoflurane, halothane, and desflurane are 0.299 , $0.456,0.470$, and 8.62 (Table).

The total inflow of gas $\left(\mathrm{TF}_{\mathrm{in}}\right)$ equals bypass flow (BF) + chamber input flow $\left(\mathrm{CF}_{\mathrm{in}}\right)$.

$\mathrm{TF}_{\mathrm{in}}=\mathrm{BF}+\mathrm{CF}_{\mathrm{in}}$

Flow of entrained agent $(\mathrm{Fa})$ produced from a vaporizer at constant pressure (Ps) and temperature is calculated from Equation 2.

$\mathrm{Fa}=\mathrm{CF}_{\text {in }}\left(\frac{\mathrm{VPa}}{\mathrm{Ps}-\mathrm{VPa}}\right)$
TABLE Vapour pressures and volume expansion coefficients for four inhaled anaesthetics at an operating pressure (Ps) of one atmosphere and at $20^{\circ} \mathrm{C}$.

\begin{tabular}{lll}
\hline $\begin{array}{l}\text { Inhaled } \\
\text { anaesthetic }\end{array}$ & $\begin{array}{l}\text { Vapour } \\
\text { pressure }\end{array}$ & $\begin{array}{l}\text { Volume expansion } \\
\text { coefficient }(V E X)\end{array}$ \\
\hline$m m H g$ & $V E X=\frac{V P}{P s-V P}$ \\
Enflurane & 175 & 0.299 \\
Isoflurane & 238 & 0.456 \\
Halothane & 243 & 0.470 \\
Desflurane & 681 & 8.620 \\
\hline
\end{tabular}

where VPa equals the saturated vapour pressure of the agent and $\mathrm{CF}_{\text {in }}$ equals flow entering the vaporizing chamber.

\section{$\frac{\mathrm{VPa}}{\mathrm{Ps}-\mathrm{VPa}}$}

is the volume expansion coefficient.

The flow exiting the vaporizer chamber $\left(\mathrm{CF}_{\text {out }}\right)$ equals the flow entering the vaporizing chamber $\left(\mathrm{CF}_{\text {in }}\right)$ plus the flow of agent entrained $(\mathrm{Fa})$.

$\mathrm{CF}_{\text {out }}=\mathrm{CF}_{\text {in }}+\mathrm{CF}_{\text {in }}\left(\frac{\mathrm{VPa}}{\mathrm{Ps}-\mathrm{VPa}}\right)$

$\mathrm{Fa}=\mathrm{CF}_{\text {in }}\left(1+\frac{\mathrm{VPa}}{\mathrm{Ps}-\mathrm{VPa}}\right)$

The total flow exiting the vaporizer $\left(\mathrm{TF}_{\text {out }}\right)$ equals the bypass flow (BF) plus the flow entering the bypass chamber $\left(\mathrm{CF}_{\text {in }}\right)$ plus the flow of agent entrained $(\mathrm{Fa})$.

$\mathrm{TF}_{\text {out }}=\mathrm{BF}+\mathrm{CF}_{\text {in }}+\mathrm{CF}_{\text {in }}\left(\frac{\mathrm{VPa}}{\mathrm{Ps}-\mathrm{VPa}}\right)$

The percent volatile agent delivered is the flow of agent entrained divided by the total flow out $\left(\mathrm{TF}_{\text {out }}\right)$ expressed as a percent.

$$
\% \text { Agent }=\frac{\mathrm{CF}_{\text {in }}\left(\frac{\mathrm{VPa}}{\mathrm{Ps}-\mathrm{VPa}}\right)}{\mathrm{TF}_{\text {in }}+\mathrm{CF}_{\text {in }}\left(\frac{\mathrm{VPa}}{\mathrm{Ps}-\mathrm{VPa}}\right)} \times 100
$$

Rearranging Equation 4 and solving for chamber flow $\left(\mathrm{CF}_{\mathrm{in}}\right)$ yields Equation 5.

$\mathrm{CF}_{\text {in }}=\left(\frac{\% \text { agent }}{100-\% \text { agent }}\right) \mathrm{TF}_{\text {in }}\left(\frac{\mathrm{Ps}-\mathrm{VPa}}{\mathrm{VPa}}\right)$

The actual percent output of an agent-specific vaporizer that is misfilled can be calculated by substituting 
Equation 5 (using $\mathrm{VPa}$ for the vapour pressure of the agent intended for use) into Equation 4 (using $\mathrm{VP}_{\text {des }}$ for the vapour pressure of desflurane).

$\%$ Des $=\frac{\left(\frac{\text { Dial Set }}{100 \text {-Dial Set }}\right)\left(\frac{V_{P_{\text {des }}}}{P_{\text {atm }}-\mathrm{VP}_{\text {des }}}\right)\left(\frac{P_{\text {atm }}-V P a}{V P_{a}}\right) \times 100}{1+\left(\frac{\text { Dial Set }}{100 \text {-Dial Set }}\right)\left(\frac{V_{\text {des }}}{P_{\text {atm }}-V_{\text {des }}}\right)\left(\frac{P_{a t m}-V P a}{V P a}\right)}$

where

$\%$ Des $=$ Output of desflurane in percent

Dial Set $=$ Dial setting of the vaporizer in percent

$\mathrm{VP}_{\mathrm{des}}=$ Vapour pressure of desflurane

$P_{\mathrm{atm}}=$ Atmospheric pressure

$\mathrm{VPa}=$ Vapour pressure of the agent intended for use in the agent-specific vaporizer

Equation 6 was used to model desflurane output caused by misfilling.

\section{Appendix B}

\section{Cooling estimation}

Example: A Tec 5 enflurane vaporizer is misfilled with one $250 \mathrm{ml}$ bottle of desflurane. The fresh gas flow rate is $5 \mathrm{~L} \cdot \min ^{-1}$, and the dial setting is $5 \%(3 \mathrm{MAC})$. The vaporizer weighs $7 \mathrm{~kg}$, and it is composed of brass. The ambient temperature is $22^{\circ} \mathrm{C}$. How much does the vaporizer cool during the first minute? Pertinent physical properties are listed below:

Gram molecular weight of desflurane $=168$ Daltons.

Specific gravity of desflurane at $15^{\circ} \mathrm{C}=1.4672 \mathrm{~g} \cdot \mathrm{ml}^{-1}$.

Heat of vaporization of desflurane at $25^{\circ} \mathrm{C}=45.24 \mathrm{cal} \cdot \mathrm{g}^{-1}$.

Specific heat of brass $=0.0917 \mathrm{cal} \cdot{ }^{\circ} \mathrm{C}^{-1} \cdot \mathrm{g}^{-1}$.

1 At a fresh gas flow rate of $5,000 \mathrm{ml} \cdot \mathrm{min}^{-1}$, calculate the desflurane flow ( Flow $_{\text {des }}$ ) exiting the vaporizer.

(a) Inspection of Figure 2 (top) shows that initial desflurane output is $86 \%$.

(b) $0.86=\frac{\text { Flow }_{\text {des }}}{5,000 \mathrm{ml}+\text { Flow }_{\text {des }}}$

$$
\mathrm{Flow}_{\mathrm{des}}=30,714 \mathrm{ml} \cdot \mathrm{min}^{-1}
$$

2 Calculate $\mathrm{ml}$ of desflurane vapour produced by $1 \mathrm{ml}$ of desflurane liquid at $22^{\circ} \mathrm{C}$.

$\left(\frac{22,400 \mathrm{ml} \text { desflurane vapour }}{\text { mole }}\right)\left(\frac{\mathrm{mole}}{\mathrm{gw}}\right)\left(\frac{1 \mathrm{gw}}{168 \mathrm{~g}}\right)\left(\frac{1.4672 \mathrm{~g}}{1 \mathrm{ml} \text { liquid }}\right)\left(\frac{295^{\circ} \mathrm{C}}{273^{\circ} \mathrm{C}}\right)=\frac{211 \mathrm{ml} \text { desflurane vapour }}{1 \mathrm{ml} \text { desflurane liquid }}$

3 Calculate the quantity of desflurane liquid vaporized during one minute.

$30,714 \mathrm{ml}$ vapour $\left(\frac{1 \mathrm{ml} \text { liquid }}{211 \mathrm{ml} \text { vapour }}\right)=\frac{146 \mathrm{ml} \text { liquid vaporized }}{\min }$

4 Calculate the quantity in grams of desflurane vaporized during the first minute.

$$
\left(\frac{146 \mathrm{ml} \text { liquid }}{\min }\right)\left(\frac{1.4672 \mathrm{~g}}{\mathrm{ml} \text { liquid }}\right)=\frac{214 \mathrm{~g}}{\min }
$$


5 Calculate the calories consumed during one minute due to vaporization.

$$
\left(\frac{214 \mathrm{~g}}{\min }\right)\left(\frac{45.24 \mathrm{cal}}{\mathrm{g}}\right)=\frac{9,681 \mathrm{cal}}{\min }
$$

6 Using the specific heat for a $7 \mathrm{~kg}$ brass vaporizer, determine the calories necessary to cool the vaporizer by $1^{\circ} \mathrm{C}$.

$$
7,000 \mathrm{~g}\left(\frac{0.093 \mathrm{cal}}{(\mathrm{g})\left({ }^{\circ} \mathrm{C}\right)}\right)=\frac{651 \mathrm{cal}}{{ }^{\circ} \mathrm{C}}
$$

7 Using the number of calories consumed by vaporization (step 5) and the number of calories necessary to cool the vaporizer by $1^{\circ} \mathrm{C}$ (step 6 ), determine the temperature decrease during the first minute.

$$
\left(\frac{9,681 \mathrm{cal}}{1 \mathrm{~min}}\right)\left(\frac{{ }^{\circ} \mathrm{C}}{651 \mathrm{cal}}\right)=\frac{14.7^{\circ} \mathrm{C}}{\min }
$$

\section{References}

1 Jones RM. Desflurane and sevoflurane: inhalation anaesthetics for this decade? $\mathrm{Br} \mathrm{J}$ Anaesth 1990; 65: 527-36.

2 Rampil IJ, Lockhart SH, Zwass MS, et al. Clinical characteristics of desflurane in surgical patients: minimum alveolar concentration. Anesthesiology 1991; 74: 429-33.

3 Eger EI II. Partition coefficients of I-653 in human blood, saline, and olive oil. Anesth Analg 1987; 66: 971-3.

4 Taylor RH, Lerman J. Induction, maintenance and recovery characteristics of desflurane in infants and children. Can J Anaesth 1992; 39: 6-13.

5 Jones RM, Koblin DD, Cashman JN, Eger EI II, Johnson $B H$, Damask MC. Biotransformation and hepato-renal function in volunteers after exposure to desflurane (I-653). Br J Anaesth 1990; 64: 482-7.

6 Rendell-Baker L. Problems with anesthetic gas machines and their solutions. Int Anesthesiol Clin 1982; 20: 45-7.

7 Dorsch JA, Dorsch SE. Understanding Anesthesia Equipment: Construction, Care and Complications. 2nd ed. Baltimore: Williams \& Wilkins, 1984.
8 Karis $J H$, Menzel $D B$. Inadvertent change of volatile anesthetics in anesthesia machines. Anesth Analg 1982; 61: 53-5.

9 George TM. Failure of keyed agent-specific filling devices (Letter). Anesthesiology 1984; 61: 228-9.

10 Riegle EV, Desertspring $D$. Failure of the agent-specific filling device (Letter). Anesthesiology 1990; 73: 353-4.

11 Rodgers RC, Hill GE. Equations for vapour pressure versus temperature: derivation and use of the Antoine equation on a hand-held programmable calculator. $\mathrm{Br} \mathrm{J}$ Anaesth 1978; 50: 415-24.

12 Dorsch $J A$, Dorsch SE. Understanding Anesthesia Equipment: Construction, Care and Complications. 1st ed. Baltimore: Williams \& Wilkins, 1975.

13 Tec 6 Vaporizer. Operation and Maintenance Manual. Steeton, England: Ohmeda, The BOC Group, April 1992. 